Syntax Literate : Jurnal Ilmiah Indonesia p-ISSN: 2541-0849 e-ISSN : 2548-1398

Vol. 6, No. 3, Maret 2021

\title{
IMPLEMENTASI PEMBERIAN ASI EKSKLUSIF PADA BAYI DENGAN IBU POST SECTIO CAESAREA DI RUMAH SAKIT
}

\author{
Hetty W.A. Panggabean dan Ontran Sumantri Riyanto \\ Politeknik Kesehatan Kementerian Kesehatan Medan dan Sekolah Tinggi Ilmu \\ Kesehatan Bethesda Yakkum Yogyakarta, Indonesia \\ Email: hettypanggabean54@gmail.com dan ontran27@yahoo.co.id
}

\section{Abstract}

Post sectio caesarean mothers in the hospital, in accordance with the existing regulations must give exclusive breast milk. Data obtained from the Indonesian Health Demographic Survey in 2017 increased exclusive breastfeeding from 2012 by $42 \%$ to $52 \%$ in 2017. But if reviewed it turns out that exclusive breastfeeding decreases with the age of children from $67 \%$ at the age of $0-1$ months to $55 \%$ at the age of 2-3 months and 38 percent at the age of 4-5 months. This study aims to find out the causative factors in post sectio caesarean mothers do not give exclusive breast milk to their babies and to know the implementation of exclusive breastfeeding in infants with post sectio caesarean mothers at the Lake Area Hospital in 2020. This research method is empirical juridical research, the research specification in this study is descriptive analytical. The results showed from 60 respondents Post sectio caesarean section and 22 health workers obtained that the baby has not received early breastfeeding initiation and exclusive breast milk and generally uses formula milk Conclusion that post sectio caesarean mothers are still not fully conducted throughout the research site, national policy is needed to support exclusive breast milk for mothers and babies post sectio caesarean.

Keywords: post sectio caesarea; breast milk; infants; health

\begin{abstract}
Abstrak
Ibu post sectio caesarea di rumah sakit, sesuai dengan peraturan yang ada harus memberikan ASI eksklusif. Data yang diperoleh dari survey demografi kesehatan Indonesia tahun 2017 adanya peningkatan pemberian ASI eksklusif dari tahun 2012 yaitu $42 \%$ menjadi $52 \%$ pada tahun 2017 . Tetapi jika dikaji ternyata pemberian ASI eksklusif menurun seiring dengan bertambahnya usia anak dari $67 \%$ pada usia 0-1 bulan menjadi 55\% pada usia 2-3 bulan dan 38 persen pada usia 4-5 bulan. Penelitian ini bertujuan untuk mengetahui faktor-faktor penyebab pada ibu post sectio caesarea tidak memberikan ASI eksklusif pada bayinya dan mengetahui implementasi pemberian ASI eksklusif pada bayi dengan ibu post sectio caesarea di Rumah Sakit Kawasan Danau Tahun 2020. Metode penelitian ini adalah penelitian yuridis empiris, spesifikasi penelitian dalam penelitian ini adalah deskriptif analitis. Hasil penelitian menunjukkan dari 60 responden ibu post sectio caesarea dan 22 tenaga kesehatan didapatkan bahwa bayi belum mendapat inisiasi menyusui dini dan ASI ekskusif dan pada umumnya mengunakan susu formula.
\end{abstract}


Kesimpulan bahwa ibu post sectio caesarea masih belum sepenuhnya dilakukan diseluruh lokasi penelitian, dibutuhkan kebijakan nasional untuk mendukung ASI ekslusif bagi ibu dan bayi post sectio caesarea.

Kata kunci: post sectio caesarea; air susu ibu; bayi; kesehatan

\section{Pendahuluan}

Kesehatan merupakan hak asasi manusia yang diperoleh untuk meningkatkan derajat kesehatan baik masyarakat (Kementerian Kesehatan RI. 2015), kelompok dan individu, termasuk juga kesehatan ibu dan anak. Kesehatan ibu dan anak menjadi prioritas utama, sehingga dapat melahirkan generasi yang sehat dan cerdas (RISKESDAS 2018). Hal ini tertuang pada Pasal 126 dan Pasal 131 UU UndangUndang No. 36 Tahun 2009 tentang Kesehatan. Jaminan kesehatan anak menjadi tanggung jawab semua pihak, baik orang tua, keluarga, masyarakat, pemerintah, dan pemerintah daerah (Kementerian Kesehatan RI Badan Penelitian dan Pengembangan 2018). Memperoleh derajat kesehatan yang setinggi-tingginya merupakan hak dasar ibu dan anak, sebagaimana diatur dalam Pasal 49 dan Pasal 62 Undang-Undang No.39 Tahun 1999 tentang Hak Asasi Manusia (HAM).

World Health Organization (WHO) telah menetapkan standar rata-rata disuatu negara, yaitu 5-15\% dari setiap seribu kelahiran di dunia, namun menurut data WHO, dari tahun 2007 hingga 2008, angka kelahiran SC di semua negara, mengalami peningkatan yaitu 110.000 per kelahiran untuk angka kelahiran se-Asia (WHO 2017). Faktor yang menyebabkan persalinan dengan CS adalah usia ibu, paritas dan kejadian anemia.

Persalinan SC pasti akan mempengaruhi akan kebutuhan fisik bayi (Susanto 2019). Salah satu kebutuhan fisik bayi setelah lahir adalah air susu ibu yang selanjutnya disebut ASI. Pemberian ASI pada satu jam pertama setelah melahirkan akan meningkatkan ikatan antara ibu dan anak yang disebut inisiasi menyusui dini yang selanjutnya disebut IMD. Pemberian ASI sedini mungkin tentunya akan mempengaruhi keberhasilan program pemberian ASI eksklusif pada bayi (Intani, Syafrita, and Chundrayetti 2019).

Angka cakupan ASI eksklusif berbeda-beda di setiap negara (Suliasih, Puspitasari, and Dwi Pawestri 2019). Hasil survei yang dilakukan oleh Center for Disease Control and Prevention (CDC) di Amerika pada tahun 2014 menunjukkan bahwa hanya 40,7\% bayi yang mendapatkan ASI eksklusif sebelum tiga bulan dan cuma 18,8\% bayi yang telah mendapatkan ASI eksklusif hingga usia enam bulan. (Center for Disease Control \& Prevention 2019). Data yang diperoleh dari Survey Demografi Kesehatan Indonesia pada tahun 2017(Kemenkes RI 2017) menunjukkan bahwa sejak tahun 2012 pemberian ASI Eksklusif mengalami peningkatan, dari 42\% pada 2017 menjadi 52\%. Namun jika dikaji ternyata pemberian ASI Eksklusif berkurang seiring dengan bertambahnya usia anak dalam pemberian ASI, pada usia bayi 0-1 bulan mencapai 67\%, usia bayi 2-3 bulan hanya $55 \%$ dan $38 \%$ pada usia bayi $4-5$ bulan (BKKBN 2017). 
Pasal 6 dan 7 Peraturan Pemerintah Nomor 33 Tahun 2012 tentang Pemberian ASI eksklusif mengatur bahwa setiap ibu yang melahirkan wajib memberikan ASI eksklusif kepada bayinya kecuali terdapat indikasi medis bahwa ibu tidak ada atau terpisah dari bayi. ASI yang tidak lancar atau sedikit keluarnya cairan dapat membuat bayi mudah rewel karena kebutuhan asupan makanan bayi tidak dapat terpenuhi. ASI yang tidak dapat memenuhi kebutuhan bayi pasti akan berpengaruh pada tumbuh kembang bayi. Waktu untuk pengeluaran ASI pada ibu pasca SC lebih lambat dibandingkan pada ibu postpartum normal. Keterlambatan pengeluaran ASI ibu pasca SC disebabkan oleh berbagai faktor, antara lain posisi menyusui, nyeri setelah SC, mobilisasi, rawat gabung dalam pengasuhan ibu dan anak, dan intervensi rolling massage (Desmawati 2013).

Ibu yang menggunakan obat penghilang rasa sakit seperti epidural atau SC saat melahirkan memiliki risiko lebih tinggi mengalami keterlambatan pengeluaran air susu. Penelitian sebelumnya telah menunjukkan bahwa efek anestesi selama persalinan meningkatkan waktu laktogenesis hingga 13 jam. Keterlambatan proses laktasi ibu post SC juga dikaitkan dengan penurunan kadar hormon oksitosin akibat penggunaan obat anestesi. (Agustin and Septiyana 2018), Hormon oksitosin sendiri merupakan hormon yang merangsang produksi ASI. Proses menyusui ibu pasca SC dapat tertunda dalam 45 hari pertama setelah melahirkan (Rinawati 2019).

Keterlambatan proses menyusui dapat mempengaruhi penurunan berat badan bayi (Sutanto 2018). Pada minggu pertama kehidupan, berat badan bayi baru lahir adalah hal yang wajar jika terjadi penurunan. Berdasarkan penelitian Prof. Valerie Flaherman dari Universitas California of San Frasisco (Flaherman and Lee 2013), terdapat perbedaan antara bayi yang lahir secara spontan pervaginam dengan yang lahir melalui operasi caesar. Berat badan bayi yang lahir pervaginam akan turun ke titik terendah pada 54-60 jam, sedangkan bayi yang baru lahir melalui operasi caesar akan mencapai titik terendah pada 60-72 jam, maka keduanya memerlukan dengan perhatian khusus Jika angka kelahiran turun $>10 \%$ berat badan atau Penurunan berat badan $>7 \%$ yang disertai gejala klinis yang menunjukkan bahwa bayi kurang sehat. Pemberian ASI eksklusif secara nasional pada tahun 2010-2012 hanya 33,6-35\%. Menyusui adalah perilaku kesehatan multidimensional yang dipengaruhi oleh interaksi dari faktor sosial, demografi, biologi, pre/postnatal, dan psikologi(Kurniawan 2013).

\section{Metode Penelitian}

Penelitian ini menggunakan pendekatan yuridis empiris (Abdul Kadir 2015), penelitian ini mengkaji regulasi kemudian menggabungkan datapada dokter obgin, dokter anak, bidan, konsultan ASI, ibu pasca SC, dan bayi baru lahir di rumah sakit. Kajian ini memberikan gambaran secara rinci, sistematis dan menyeluruh dari segala sesuatu yang diteliti seperti perlindungan kepada dokter obgin, dokter anak, bidan, dan ibu pasca SC dari risiko pemberian ASI eksklusif pada ibu dan bayi pasca SC. Lokasi penelitian adalah RSUD Tarutung Kabupaten Tapanuli Utara, RSUD Doloksanggul dan RSUD Porsea. Subjek penelitian yang menjadi sasaran penelitian, terhadap implementasi Peraturan Pemerintah No.33 Tahun 2012 tentang Pemberian ASI 
Eksklusif pada bayi dengan ibu post SC di rumah sakit. Teknik pengumpulan data dalam penelitian ini dilakukan dengan dua cara: yaitu pelitian lapangan dan penelitian kepustakaan dan analisis data dalam penelitian ini dilakukan secara kualitatif (Noor 2017).

\section{Hasil dan Pembahasan}

Pemberian ASI Eksklusif merupakan program pemerintah (Sukarini 2015) yang telah tertuang dalam Peraturan Pemerintah Nomor 33 Tahun 2014 tentang Pemberian ASI Eksklusif. Pemerintah sebenarnya giat mempromosikan ASI eksklusif melalui seminar, lokakarya, dan iklan di media cetak, elektronik, dan sosial. Namun hal ini tidak membuat pemberian ASI Eksklusif dapat berhasil sesuai dengan yang diharapkan. Banyak kendala yang dihadapi ibu, diantaranya faktor eksternal dan internal terutama ibu yang pernah menjalani operasi caesar setelah Post Sectio Caesarea (Amperaningsih and Siwi 2018).

Pada dasarnya dokter anak mendukung program ASI Eksklusif dari pemerintah, namun karena keterbatasan tenaga, mereka tidak bisa berkonsentrasi apalagi ikut mendampingi dan mendampingi ibu selama menyusui (Dewi 2019). Secara umum ibu menolak memberikan ASI dengan alasan ibu masih lemah, bekas luka operasi yang menyakitkan dan tidak bisa duduk (Ginting, Zuska, and Simanjorang 2019). Meski begitu, dokter anak tetap menganjurkan untuk menyusui. Hasil penelitian dokter tidak pernah menawarkan untuk memberikan susu formula kepada keluarga bayi, karena keluarga telah menyediakan sendiri dan memberikan susu formula dengan alasan ibu tidak dapat memberikan ASI dan ASI tidak keluar. Sehingga tidak pernah ada kasus dehidrasi bahkan kematian akibat mempertahankan menyusui (Afritayeni 2017).

Ibu yang SC semuanya menggunakan anastesi lokal/spinal. Anastesi spinal yang diberikan saat SC menurut dokter tersebut tidak mengganggu pelaksanaan inisiasi menyusui dini di ruang operasi tetapi kembali lagi kepada kesediaan atau persetujuan ibu untuk melakukannya.

Data yang dikumpulkan peneliti menunjukkan riwayat SC ibu post sectio caesarea sebesar $67 \%$ atau sebanyak $36 \mathrm{ibu}$, dan yang kedua atas permintaan ibu sebanyak 23,33\%. Hasil kajian dari penelitian ini juga melihat hasil responden dari ibu SC menunjukkan bahwa pemberian ASI tidak dimulai sejak dini dan semua bayi diberikan susu formula oleh ibu dan anggota keluarga. Tidak ada arahan dan bimbingan kepada ibu, tetapi ibu dianjurkan untuk menyusui. Ibu SC menganggap ASI-nya tidak cukup, sehingga bayinya rewel, dan akhirnya diberi susu formula (Enamberea et al. 2020). Konselor ASI tidak akan pernah menyarankan memberikan susu formula kepada ibu atau anggota keluarganya, membimbing dan mendampingi ibu dalam pemberian ASI jika diminta keluarga, sehingga tidak ada temmuan ada bayi yang dehidrasi atau mengalami kematian karena mempertahankan pemberian ASI Eksklusif (Ardie and. 2017). Pada dasarnya konselor ASI mendukung pemberian ASI dini dan ASI eksklusif, namun banyak ibu yang percaya bahwa ibu mereka masih kesakitan akibat bekas operasi, meskipun demikian menyarankan untuk memberikan ASI Eksklusif.. 
Pemberian ASI Eksklusif pada bayi merupakan suatu kewajiban bagi seluruh ibu, mengingat seluruh penyelenggara maupun sarana fasilitas kesehatan dalam hal ini rumah sakit harus mendukung keberhasilan program pemberian ASI Eksklusif dengan cara memberikan pelatihan pada seluruh tenaga kesehatan yang berhubungan dengan kesehatan bayi. Pelatihan ini diberikan terutama kepada dokter obgyn, dokter anak, bidan, konselor ASI yang mana dimulai sejak kehamilan, pada saat pemeriksaan kehamilan sampai ibu nifas melalui penyuluhan secara berkesinambungan di rumah sakit, hal ini bisa dilakukan dengan menggunakan media televisi di ruang tunggu pelayanan, menunjukkan gambar, membuat poster di ruang pemeriksaan kehamilan, di ruang rawat inap ibu post sectio caesarea dan di ruang neonates.

Rumah sakit juga harus mendukung ibu untuk tidak memberikan dot bayi dimana pada hari pertama persalinan perlu diberikan pengetahuan dan ionformasi kepada ibu yang umumnya belum mengeluarkan ASI, sebab secara fisiologis setelah pengeluaran placenta maka terjadi penurunan progesterone yang menurun sampai nilai 0 , dan akan meningkat hormone oxytosin dan prolactin selama 2-3 hari. Jumlah ASI akan meningkat jumlahnya sesuai kebutuhan bayi setelahnya. Berdasarkan hasil penelitan seluruh rumah sakit yang diteliti dari seluruh responden tidak melakukan inisiasi menyusui dini, dengan alasan belum ada ASI keluar, dan juga faktor ibu masih kesakitan.

Menurut Peraturan Pemerintah no 33 tahun 2012, dinyatakan bahwa salah satu dari 10 menuju kesuksekan dalam mendukung ASI eksklusif antara lain membantu ibu menyusui dini dalam 60 menit pertama persalinan tetapi kenyataannya dari 60 responden tidak melakukan inisiasi menyusui dini, selain itu juga pemberian ASI ini juga perlu dukungan dari peran suami (Widoyo 2017).

Ditinjau dari perspektif hak asasi manusia, mendapatkan ASI merupakan hak bayi utnuk mendapatkan asupan gizi (Kemenkes RI Dirjen P2P 2020). Banyak peraturan yang telah dibuat pemerintah untuk mendukung pemberian ASI Ekslklusif sebagai salah satu pemenuhan atas hak anak. Peraturan tersebut terdapat pada Penjelasan Pasal 9 Undang- Undang No. 39 Tahun 1999 tentang Hak Asasi Manusia dijelaskan bahwa setiap orang berhak atas kehidupan, mempertahankan kehidupan, dan meningkatkan taraf kehidupannya tidak terkecuali bayi baru lahir. Diatur juga pada Pasal 8 UndangUndang No. 23 Tahun 2002 tentang Perlindungan Anak menjelaskan bahwa "setiap anak berhak memperoleh pelayanan kesehatan dan jaminan sosial sesuai dengan kebutuhan fisik, mental, spiritual, dan sosial. Pelayanan kesehatan yang dimaksud disini salah satunya adalah pemberian ASI Eksklusif di rumah sakit. Undang-Undang Kesehatan juga mendukung hal yang sama yang dijelaskan pada Pasal 128 ayat 1 Undang-Undang No.36 Tahun 2009 bahwa setiap bayi berhak mendapatkan air susu ibu eksklusif sejak dilahirkan selama 6 (enam) bulan, kecuali atas indikasi medis. Bahkan pemerintah secara khusus membuat peraturan tentang pemberian ASI Eksklusif, yaitu Peraturan Pemerintah No.33 Tahun 2012. Lahirnya peraturan ini menunjukkan bahwa pemerintah serius dan fokus tentang pemberian ASI Eksklusif. Besarnya manfaat pemberian ASI Esksklusif, tentunya tidak lepas dari dukungan berbagai pihak termasuk tenaga kesehatan dalam hal ini dokter obgyn, dokter anak, bidan dan perawat yang ada 
di rumah sakit hal ini sesuai dengan Pasal 13 Peraturan Pemerintah No.33 Tahun 2012 tentang Pemberian ASI Eksklusif.

Manfaat pemberian ASI Eksklusif tidak saja hanya kepada bayi itu sendiri tetapi juga kepada ibu dan keluarga bahkan masyarakat (Haryono and Setianingsih 2014). Manfaat pemberian ASI Eksklusif bagi bayi diantaranya ASI tersedia dalam kondisi steril, dan suhu yang tepat sehingga mengurangi risiko diare, mudah dicerna sehingga mengurangi kerusakan usus, pemberian ASI dapat mengurangi berbagai risiko penyakit seperti infeksi, penyakit jantung, kerusakan gigi, obesitas dan lain-lain, dan ASI memiliki semua zat yang dibutuhkan bayi sehingga nutrisinya bisa yang terpenuhi. Kebutuhan nutrisi yang terpenuhi akan menunjang perkembangan otak sehingga memiliki IQ yang lebih tinggi dibandingkan dengan anak yang tidak diberi ASI. Manfaat pemberian ASI bagi ibu (Lindawati 2019), diantaranya pertama meningkatkan kontrasi Rahim sehingga mengurangi risiko terjadinya perdarahan, kedua dapat mengurangi inside kanker payudara, ketiga mengurangi risiko diabetes dan keempat merupakan salah satu metode kontrasepsi yang aman dan efektif.

\section{Kesimpulan}

Implementasi Pemberian ASI Eksklusif belum diterapkan pada ibu post sectio caesarea di rumah sakit, dan perlunya dukungan lebih dari tenaga kesehatan seperti dokter kandungan, dokter anak, bidan dan konselor ASI sangat diperlukan untuk memberikan informasi dan edukasi tentang ASI Eksklusif kepada ibu post sectio caesarea. Perlu meningkatkan pengetahuan SDM kesehatan untuk pemberian ASI Eksklusif, agar seluruh bayi yang lahir dengan sectio caesarea mendapat inisiasi menyusui dini dari ibunya sebagai menjadi awal kesuksesan pemberian ASI. Dalam rangka melaksanakan Peraturan Pemerintah Nomor 33 Tahun 2012 tentang ASI Eksklusif, perlu disusun kebijakan rumah sakit yang mendorong partisipasi dalam memfasilitasi tenaga SDM kesehatan untuk mengikuti seminar, workshop maupun pelatihan. 
Hetty W.A. Panggabean dan Ontran Sumantri Riyanto

\section{BIBLIOGRAFI}

Abdul Kadir, Muhammad. 2015. "Hukum Dan Penelitian Hukum." Bandung : PT. Citra Aditya Bakti.

Afritayeni, Afritayeni. 2017. "Pola Pemberian Makan Pada Balita Gizi Buruk Di Kelurahan Rumbai Bukit Kecamatan Rumbai Kota Pekanbaru Provinsi Riau." Jurnal Endurance. doi: 10.22216/jen.v2i1.1598.

Agustin, Ike Mardiati, and Septiyana Septiyana. 2018. "Kecemasan Pada Ibu Post Partum Primipara Dengan Gangguan Proses Laktasi." Jurnal Ilmu Keperawatan Jiwa. doi: 10.32584/jikj.v1i2.133.

Amperaningsih, Yuliati, and Purwanti Nugrahanti Siwi. 2018. "Stres Pasca Trauma Pada Ibu Post Partum Dengan Sectio Caesarea Emergency Dan Partus Spontan." Jurnal Ilmiah Keperawatan Sai Betik. doi: 10.26630/jkep.v14i1.1011.

Ardie, Fanny, and . Prasodjo. 2017. "Perbedaan Frekuensi Regurgitasi Pada Bayi Usia 0-6 Bulan Aterm Yang Diberi Asi Eksklusif Dan Susu Formula Di Wilayah Kerja Puskesmas Balongsari Kotamadya Mojokerto." Saintika Medika. doi: 10.22219/sm.v8i2.4110.

BKKBN. 2017. Survey Demografi Dan Kesehatan Indonesia.

Center for Disease Control \& Prevention. 2019. "Pregnancy Mortality Surveillance System." $C D C$.

Desmawati. 2013. "Penentu Kecepatan Pengeluaran ASI Setelah Sectio Caesaria." Kesmas: Public Health Journal.

Dewi, Ayu Devita Citra. 2019. "Faktor-Faktor Yang Mempengaruhi Kelancaran Produksi Asi." Jurnal 'Aisyiyah Medika. doi: 10.36729/jam.v4i1.230.

Enamberea, Rosita Rahel, Maria Dyah Kurniasari, Dary, and Kukuh Pambuka Putra. 2020. "Pemberian Asi Eksklusif, Susu Formula Dan Kombinasi Keduanya Terhadap Pertumbuhan Dan Perkembangan Anak Usia 6-11 Bulan Di Puskesmas Cebongan Salatiga.” Jurnal Ilmu Keperawatan Dan Kebidanan.

Flaherman, Valerie J., and Henry C. Lee. 2013. "“Breastfeeding' by Feeding Expressed Mother's Milk." Pediatric Clinics of North America.

Ginting, Enni Prina, Fikarwin Zuska, and Asyiah Simanjorang. 2019. "Faktor-Faktor Yang Memengaruhi Kegagalan Inisiasi Menyusui Dini Pada Ibu Post Sectio Caesarea Di Rumah Sakit Tentara Binjai Tahun 2018." Jurnal Kesehatan Perintis (Perintis's Health Journal). doi: 10.33653/jkp.v6i1.213.

Haryono, Rudi, and Sulis Setianingsih. 2014. Manfaat ASI EKSKLUSIF Untuk Buah Hati Anda. 
Intani, Trya Mia, Yuliarni Syafrita, and Eva Chundrayetti. 2019. "Hubungan Pemberian ASI Eksklusif Dan Stimulasi Psikososial Dengan Perkembangan Bayi Berumur 612 Bulan.” Jurnal Kesehatan Andalas. doi: 10.25077/jka.v8i1s.920.

Kemenkes RI. 2017. Survey Demografi Dan Kesehatan Indonesia.

Kemenkes RI Dirjen P2P. 2020. "Berikan ASI Untuk Tumbuh Kembang Optimal." Kementerian Kesehatan RI.

Kementerian Kesehatan RI. 2015. Kementerian Kesehatan Republik Indonesia.

Kementerian Kesehatan RI Badan Penelitian dan Pengembangan. 2018. "Riset Kesehatan Dasar 2018." Kementrian Kesehatan Republik Indonesia.

Kurniawan, Bayu. 2013. "Determinan Keberhasilan Pemberian Air Susu Ibu Eksklusif." Jurnal Kedokteran Brawijaya. doi: 10.21776/ub.jkb.2013.027.04.11.

Lindawati, Revi. 2019. "Hubungan Pengetahuan, Pendidikan Dan Dukungan Keluarga Dengan Pemberian ASI Eksklusif." Faletehan Health Journal. doi: 10.33746/fhj.v6i1.25.

Rinawati, Ririn. 2019. "Proses Laktasi Dan Menyusui." Journal of Chemical Information and Modeling.

RISKESDAS. 2018. "Riset Kesehatan Dasar 2018.” Kementrian Kesehatan Republik Indonesia.

Sukarini, Luh Putu. 2015. "Pengetahuan Dan Sikap Ibu Dengan Pemberian Asi Eksklusif.” Jurnal Genta Kebidanan. doi: 10.36049/jgk.v5i2.58.

Suliasih, Rokhmah Ayu, Dwiyanti Puspitasari, and Dhasih Afiat Dwi Pawestri. 2019. "Faktor Yang Berhubungan Dengan Keberhasilan ASI Eksklusif." Sari Pediatri. doi: 10.14238/sp20.6.2019.375-81.

Susanto, dkk. 2019. "Faktor-Faktor Yang Berhubungan Dengan Persalinan Sectio Caesaria." Jurnal Kesehatan Delima Pelamonia.

Sutanto, Andina Vita. 2018. Asuhan Kebidanan Nifas dan Menyusui Teori dalam Praktik Kebidanan. Yogyakarta :. Pustaka Baru Press. 2018. "Asuhan Kebidanan Nifas Dan Menyusui Teori Dalam Praktik Kebidanan.” Journal of Chemical Information and Modeling.

WHO. 2017. "Maternal, Newborn, Child and Adolescent Health." Global Strategy for Infant and Young Child Feeding.

Widoyo, Ratno. 2017. "Peningkatan Peran Suami Dalam Kesehatan Ibu Dan Anak Indonesia." Jurnal Kesehatan Masyarakat Andalas. doi: 10.24893/jkma.v9i2.211. 